\title{
"Vintage Nightlife": Gentrifying Lisbon downtown
}

\author{
JORDI NOFRE
}

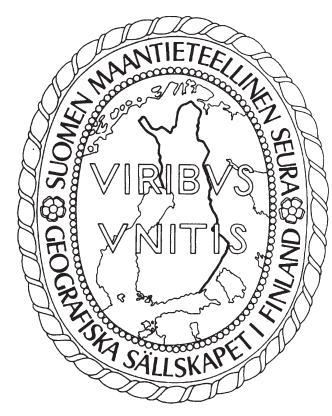

Nofre, Jordi (2013). "Vintage Nightlife": Gentrifying Lisbon downtown. Fennia 191: 2, pp. 106-121. ISSN 1798-5617.

Over last two decades, culture has played a very important role in large-scale urban transformations. In that sense, nightlife promotion has become one of the most important strategies for urban regeneration in post-industrial cities. This paper explores the newly emerged vintage-style nightlife in the former harbour quarter of Cais do Sodré (Lisbon downtown). To do this, I focus on a recently renewed hostel building called Pensão Amor - formerly frequented by sailors and prostitutes, and today considered the coolest nightlife venue in the Portuguese Capital. After presenting an updated state of the art exploration of gentrification and nightlife, I argue in the second part of my paper that Pensão Amor is currently playing a key role in the gentrification of the urban nightscape in the Cais do Sodré neighbourhood, where its traditional nightlife is today being supplanted by a vintage-style nightlife. Furthermore, I argue that the consumption of this recently promoted vintage nightlife as a new form of social distinction can be also seen as the (re)production strategy of a socially and morally sanitized nightlife which marginalizes everyone who is seen as inappropriate, or in other words, socially perilous to the city branding of Lisbon.

Keywords: vintage style, nightlife, social distinction, gentrification, Cais do Sodré Lisbon

Jordi Nofre, Faculty of Social \& Human Sciences, New University of Lisbon, Avenida de Berna, 26-C 1069-061 Lisbon, Portugal. E-mail: jnofre@fcsh.unl.pt

\section{Introduction: the rise of the 'ludic' city}

Over the past three decades, many worldwide cities have reshaped their spaces, mainly through culturally-led strategies for urban regeneration. New forms of social organization, leisure, and cultural consumption, among other factors, have recently led to the conversion of many downtowns into urban themed parks (Lefebvre 1968; Hannigan 1998; Baptista 2005). The inner city thus becomes a theatre of consumption that is socially and politically controlled (Ritzer 1993, 1998, 2010) formed by hubs of corporative leisure, which plays a key role in the city branding process. These new means of consumption - or, in the terms of George Ritzer (2010), these new cathedrals of consumption - have favoured the emergence of leisure as an organizer of contemporary social practices in the greatest post-Fordist cities, as it prevails in family, professional, and civic life (Baptista 2005). Fiesta, fun, and relaxation are therefore synonymous with success in the everyday life of our post-Fordist "ludic cities" (Baptista 2005). This new kind of leisure aims at promoting citizens as leisure producers, consumers of cultural products, and consumers of leisure spaces (Lefebvre 1968).

More than 30 years later, the document entitled Culture, The Engine of the 21st Century European Cities (approved by the Eurocities Committee in September 2001) took into account what Henri Lefebvre then had already pointed out about the consolidation of culture as one of the key strategies of large-scale urban transformations, which aim at converting citizens into consumers and creators of culture. In that sense, nightlife promotion plays a significant role in several processes of culture-led urban renovation and gentrification in today's European cities (Chatterton \& Hollands 2003; Nofre \& Martin 2009; Hael 2011). At the same time, gentrification has become a key process of urban and social transformation in reshap- 
ing contemporary worldwide cities over the last decades. This is the case of Lisbon and Cais do Sodré, one of its former harbour quarters. So in focusing on this case study, this paper will explore how the conversion of an abandoned hostel (called Pensão Amor), formerly frequented by marginal prostitutes and sailors over the last century, has been playing a key role in the gentrification of Cais do Sodré through the newly-promoted vintage style where the old, the decadent, and the sordid have been re-signified to become part of a newly-created urban nightscape of social distinction.

This paper presents the first results of a 2-year ethnographic fieldwork study of nightlife and urban change in post-industrial Lisbon. The presence of many urban processes like nightlife-based gentrification together with outlawed activities like drugs dealing, prostitution, and laundering money through drinks consumption and entrance fees demands the use of methodological eclecticism (Hannerz 1980; Wynne \& O'Connor 1998) to explore the Cais do Sodré's urban nightscape (Fig. 1). Hence, after conducting a 15-month participant observation, 32 people were interviewed in loco. The subjects of such informal interviews comprised four bouncers, three policemen, and 25 customers (the venue's owners rejected being interviewed). ${ }^{1}$ Most of interviews were manually registered in a small field notebook. The following list characterizes the informants used in this paper:

- Informant 1: male, 29 years, PhD Student, Lisbon; interview carried out on 28 January 2012, at about 2:00 a.m. inside Pensão Amor and manually registered.

- Informant 2: male, 37 years, security staff member, Lisbon; interview carried out on 15 February 2012, at about 0:30 a.m (his statements were registered in situ for obvious reasons of safety).

- Informant 3: female, 23 years, undergraduate student, Barreiro (Lisbon metropolitan area); interview carried out on 14 March 2012, at 10:00 a.m. at her Faculty building.

- Informant 4: male, 24 years, undergraduate student, Lisbon; interview carried out on 14 March 2012, at 10:00 a.m. at his Faculty building.

- Informant 5: male, 34 years, software developer, Lisbon; interview carried out inside Pensão Amor, on 12 November 2011, at about 2:15 a.m.

- Informant 6: female, 38 years, real-estate investor, Lisbon; interview carried out inside Pensão Amor, on 12 November 2011, at about 2:15 a.m.
- Informant 7: male, 30 years, postdoctoral research fellow, foreigner (Spaniard); interview carried out inside Pensão Amor, on 12 November 2011, at about 2:15 a.m.

- Informant 8: male, 50 years (approx.), police, Lisbon; interview carried out on 6 June 2012, at about 2:30 a.m.

Together with the ethnographic fieldwork, a first cartography of Lisbon's nightlife was carried out but not included in this text - to better contextualize the role that Cais do Sodré has in the nightlife system of the Portuguese capital. Therefore, this paper does not pretend to discuss what the interviewed people told, but it carries out a first approach to the gentrification of Cais do Sodré and the rise of a "distinguished" urban nightscape in downtown Lisbon based on the promotion of newly-created "vintagestyle" nightlife.

This paper uses as its starting point the definitions of "vintage" and "gentrification" appearing in the online version of the American Heritage Dictionary, which defines the second of these terms as the restoration of deteriorated urban property, especially in working-class neighbourhoods carried out by the middle and upper classes. At first glance, one might distinguish that which is abandoned, derelict, old, or simply vintage. In that sense, the Oxford Advanced American Dictionary refers to the term "vintage" as something typical of a period in the past and of high quality. Having in mind such linguistic distinctions and focusing on the case study of Cais do Sodré, the text below will attempt to show how a new cool nightscape - which is today playing a key role in gentrifying Cais do Sodré - can be seen as the result of promoting a vintage-style nightlife that is synonymous with a consumption space of social distinction, as has been previously pointed out.

When it comes to ethical issues, this research has involved tracking the localization and observation of people, and the personal data of interviewees has been manually recorded in a fieldwork notebook. Interviewees were informed about the purpose and the scientific nature of this research and were asked to give oral consent to use their narratives. Because interviewees have not had the right to check and emend the final transcription before the storage process, or the right to evidence parts of their narratives, their non-identified status has been strictly maintained, and the complete transcriptions of interviews have been stored in a database only accessible to the author of this manuscript. Finally, no participants in this research were underaged. 
FENNIA 191:2 (2013)

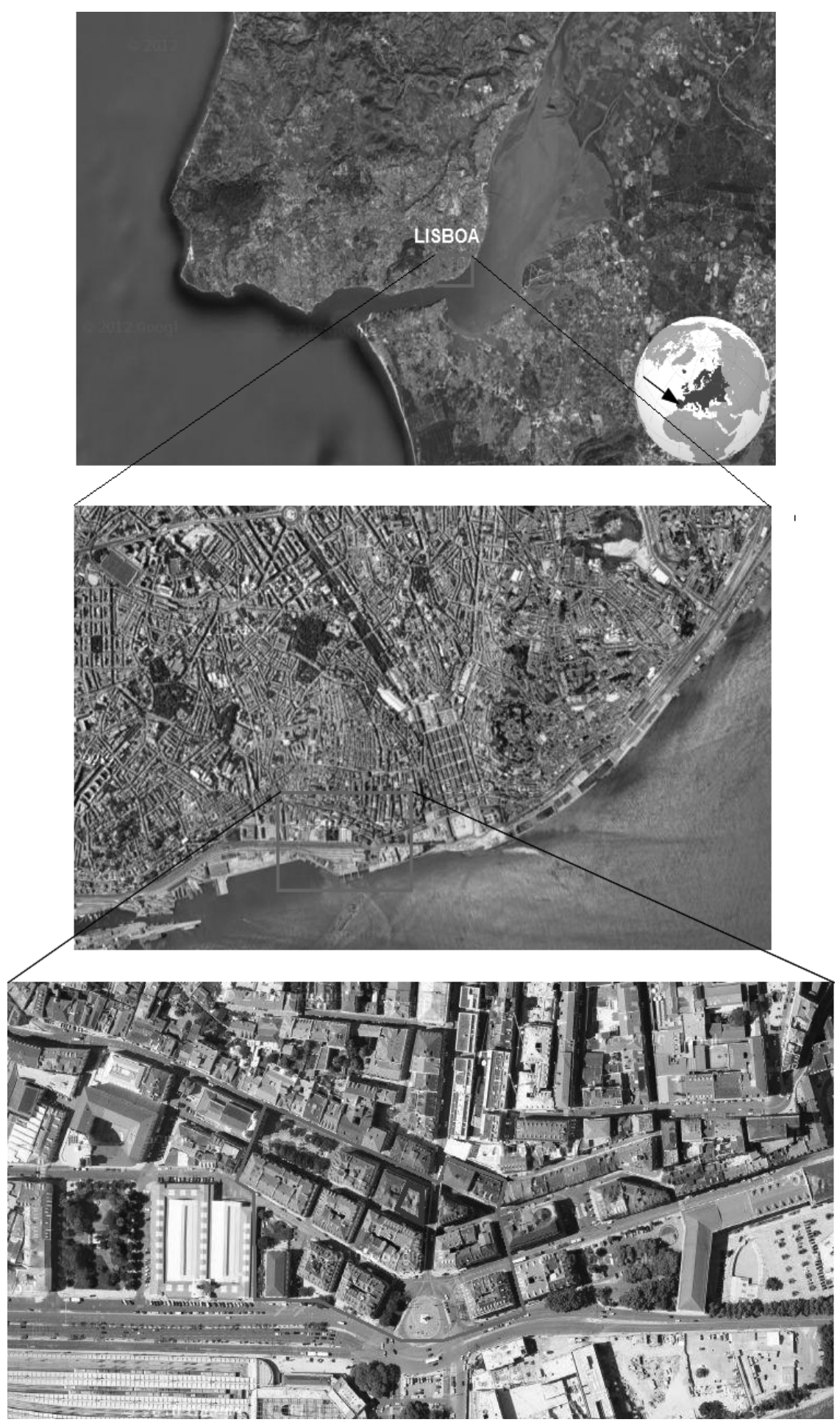

Fig. 1. Localization of Cais do Sodré (Lisbon downtown)

Source: Nofre (c) 2013. 


\section{Studying gentrification as cultural consumption and social distinction}

Although the term "gentrification" can be originally found in Memoirs and Proceedings of the Manchester Literary \& Philosophical Society written in 1888 (Atkinson \& Bridge 2008), it acquired a contemporary meaning when the British sociologist Ruth Glass (1964) used it in her book London: Aspects of Change. According to Glass, Islington's population of a low economic class was being replaced by new upper class individuals coming from other wealthier London suburbs. Over the decade of the 1970s and early 1980s, some of the first empirical works on gentrification were published. Some considered it to be a positive response to the degradation of downtowns (Ley 1986), while others theorized about gentrification as a process linked to public and private strategies on housing (Hamnett 1973; Williams 1976). In fact, the Institute of British Geographers inaugurated its Transactions by paying special attention to gentrification, which demonstrates the importance that it had gained during the 1970s. In parallel, other scholars have argued that gentrification has to do with the existence of urban inequalities as a consequence of the processes of urban regeneration (Smith 1979a, 1979b; Berry 1980; Ley 1980).

From the beginning of the 1980s, gentrification began to affect many areas of cities, not only in Britain, but also around the world. Neil Smith (1979b), in his study on gentrification of the Society Hill borough in Philadelphia, pointed out that gentrification had become fundamental in the restructuring of urban space because this particularly depended on the volume of productive capital returning to the gentrified central area. Such an explanation of gentrification must be considered as the basis of the so-called rent-gap theory, further developed in many papers published by Neil Smith himself and by many other authors. After Smith's paper, another two economists' theories emerged: Hamnett and Randolph's (1984, 1986) value-gap explanation, and the consumption-side explanation of gentrification. This latter focused on the key role that consumption and culture played in the process of gentrification in the New York neighbourhood of Soho (Zukin 1982). By taking culture and consumption into account as key categories for the geographical analysis of gentrification, some scholars have suggested new approaches to answering the "hows", "whos", and "whys" of gentrification. In that sense,
Sharon Zukin (1982) mixed both the productionand consumption-side models of explanation. In the due course of time, her work has become a new epistemological paradigm for studying recent processes of gentrification in worldwide cities.

During the 1990s, many authors have underlined the rapid (re)production of gentrification around the world. However, some have suggested the existence of two kinds of gentrification; on the one hand, "US gentrification", and on the other hand, "European gentrification" (Musterd \& van Weesep 1991; Lees 1994; Lees \& Bondi 1995). In their study based on the inner London borough of Islington and on Park Slope, which is a part of the Brooklyn borough of New York City, Lees and Bondi (1995) noted that in the case of European cities the greatest urban areas were redeveloped due to the interventionist role of the State. However, in the case of the US cities, the role of the State was quasi-noninterventionist. However, there could be a wide discussion about this, taking into account the recent cases of gentrification in uptown Brooklyn (New York) and French Quarter in post-Katrina New Orleans. Although globalization has led to the homogenization of processes of gentrification in worldwide capitalist cities (especially after the fall of the Berlin Wall and the communist bloc), many authors continue to agree that gentrification expresses a process of class change in a previously degraded area (Smith 1996; Butler 2007). In fact, many authors consider that gentrification is best explained if it is considered as the social and spatial manifestation of the transition from an industrial to a post-industrial economy (Butler 1997; Ley 1997; Lees 2000; Hamnett 2003).

During recent years, many authors have underlined the relationship between residential market regeneration, housing policies, and gentrification in several cities around the world. Such diffusion of gentrification around the world is related to globalization, since (neoliberal) urban governments adopt gentrification as the unique strategy for urban regeneration (Atkinson \& Bridge 2008). Actually today's processes of gentrification are densely connected to the circuits of global capital and cultural circulation (Smith 2002). More specifically, this includes the promotion of a "distinguished" nightlife, not only as a form of cultural or leisure consumption, but also as a strategy for the social sanitization of the inner city. This new form of nightlife adopts re-signified elements of the local nightscape.

The term "social sanitization" is rarely used in social and human sciences, although some authors 
from the field of medieval studies, social and cultural history, criminology, and more recently from the field of urban policy have analysed how social sanitization has been executed by several different institutional bodies (Weatherly 1926; Stearns 1936, and more recently, Miraftab 2007; Vangby \& Jensen 2009; Welch 2009). The improvement of punishment, the imprisonment of deviants, or even the social sanitization in regenerating a degraded urban area are some examples of this rare, scarce use of the term "social sanitization" among today's scholars. In fact, its roots come from the Chicago's Criminology School of the first decades of the twentieth century, whose research efforts were mainly focused on how local institutions punished (young) deviant individuals - such as the Chicago's StreetCorner Boys (Thrasher 1926; Whyte 1943) - to clean the industrial city. However, more than eighty years later, a new gentrification-sanitizing strategy is once again being carried out by the Chicago City Council in order to support one of the strategies of the capital to restructure its Spanish-speaking neighbourhoods (Wilson \& Grammenos 2005). Here, social sanitization has to do with that idea of "civilizing a society", as Ulysses G. Weatherly (1926) explored in the case of the role of American experts in post-revolutionary Haiti. Therefore, social sanitization and the fact of civilizing a community or neighbourhood involves its moral sanitation - in the terms of Ernest R. Groves (1916). So the relationship between gentrification, and social and moral sanitization - that is to say, the promotion of new (Christian, bourgeois) values and behavioural ways should not be disassociated from the institutionallysupported promotion of the (young) neoliberal worker (Walker \& Finchman 2011).

Coming back to our case study, here social sanitization is conceived in the same sense that John Galtung (1958) suggested in his The Social Functions of a Prison, where the author argued that social sanitization had to do with the attempt carried out by institutions to decrease to zero the visibility of selected types of deviants. If we consider here the criminalization of "being young" (Castells 2012; Nofre \& Feixa 2013) as part of the recent instauration of the Neoliberal Penal State (Wacquant 2008) in post-industrial countries, the definition provided by Galtung acquires great timeliness in these last decades of "zero-tolerance politics" that feature the neoliberal city (Garnier 2010). Furthermore, I have implicitly used the Galtung's definition in some previous publications about nightlife, urban transformations, and social contestations in Euro-Medi- terranean cities such as Lisbon, Barcelona, and Sarajevo (Nofre \& Martín 2009; Nofre 2011; Nofre \& Feixa 2013).

This paper intends to explore how social sanitization works in the case of the Cais do Sodré neigbhourhood by focusing on the role of the former prostitution hostel Pensão Amor. In this process, the original early twentieth decoration of Pensão Amor plays a key role in the rise of most distinguished nightlife space in today's Lisbon, where international DJs play what we could call as de-territorialized world music, which is "global and deterritorialized music which although coming from a specific place, ends up 'speaking to all' as it reaches the sphere of global culture" (De La Barre 2010: 140). Here the question which arises, therefore, is: Could this kind of "globalized nightlife" be considered to be a kind of the so-called "globalized gentrification" (Maeckelbergh 2012)?

\section{Promoting nightlife as strategy of gentrification}

Culture and consumption have become key issues in explaining how gentrification has evolved in cities worldwide over the last four decades. However, few studies have paid attention to the emergence of a distinguished nightlife - or clubbing, in the terms of Sara Thornton (1995) - as a consequence of gentrification and the emergence of a distinction-based lifestyle of new middle classes in global cities (Savage \& Butler 1995; Butler 1997; Wynne \& O'Connor 1998; Chatterton \& Hollands 2003). One such work is the study by David Ley (2003) on the role of artists as agents who contribute to the gentrifying of former working-class neighbourhoods in some Canadian cities, such as Toronto, Montreal, and Vancouver. But beyond gentrification, Sharon Zukin (2009) suggests focusing our attention on how the authentic city is being (re)produced every day. As Zukin argues, "these forces of redevelopment have smoothed the uneven layers of grit and glamour, swept away traces of contentious history, cast doubt on the idea that poor people have a right to live and work here too - all that had made the city authentic" (Zukin 2009: xi).

Having in mind the rise of the authentic city suggested by Sharon Zukin, the aestheticization of the everyday life of our postindustrial cities appear to be a key process in exploring the relationship be- 
tween a distinguished and socially sanitized nightlife, and gentrification (Nofre \& Martin 2009; Nofre 2011). In fact, the spatial approach to the study of nightlife has gained importance over the last decade, with its emphasis on the close relationship between the strategy of city-securitization led by the inner city's elites and the promotion of a gentrified nightlife. In that sense, Paul Chatterton and Robert Hollands (2003) released a very influential book, in which they explored the continuities and changes of corporate control in the entertainment and nightlife economies, as well as the process of the branding and theming of nightlife. They paid special attention to the emergence of segmented, sanitized, and gentrified consumer markets. In addition, the authors also explored the economic processes governing the nightlife structure in Western European cities by focusing on the interaction between youth, central nightlife, marginal nightlife, music tastes, lifestyles, and dress codes (Chatterton \& Hollands 2003). As they argued, gentrification and nightlife are associated with some of these issues, which strongly contribute to the elitization of the social space of the city. However, such a process of nightlife elitization usually involves some spatial displacements of traditional, working-class night-time leisure activities (Chatterton \& Hollands 2003). Indeed, many authors have recently explored how nightlife gentrification involves a certain spatial marginalization of working-class night-time leisure activities in today's Western cities. In some cases, such as Barcelona (Catalonia), this marginalization of old forms of nightlife responds to well-established strategies for the social sanitation and moral sanitation of its working-class suburbs (Nofre 2011). However, is all the old actually displaced or even marginalized in the nightlife of post-industrial cities such as Lisbon? But before I continue, I will present some geographical notes on Cais do Sodre and Lisbon.

\section{Brief geographical notes on Lisbon and Cais do Sodré}

The urban history of the former Cais do Sodré neighbourhood is closely linked to the urban growth of Lisbon waterfront, which has occurred since the sixteenth century (Fig. 2). During the reign of the Portuguese king Manuel I (1495-1521) new waterfront spaces were created to expand its harbour premises, such as the Santos quarter and
Cata-que-Farás (today's Cais-do-Sodré neighbourhood). These formerly muddy terrains were rapidly landfilled to build warehouses for commercial and port activities, which received loads transported by small boats coming from the big ships anchored about half a mile away from the riverside (Durão 2012).

In the second half of the twentieth century, the so-called Old Cais de Sodré gave way to the New Cais (França 2013). What over many decades was a neighbourhood that overindulged in food and drinks, peep shows, fado music, drunken sailors, some gun violence, drug trafficking, and prostitution, began to change in the mid-1970s when some traditional bars and native-run groceries were converted into small-sized discotheques (such as Jamaica Discotheque, Europa Bar, Texas Bar, and Viking). Moreover, numerous bars, then named after some world port cities (Philadelphia, Shangri-La, Tokyo, Rotterdam, Copenhagen, Liverpool, Oslo, etc.) also opened.

The neighbourhood of Cais do Sodré was then deeply rooted in its origins as a harbour environment, which featured its own urban morphology, its everyday life, and its appropriation by native-born storekeepers, local and foreigner traders, sailors, prostitutes, and so on, up until today. The popular revolution that occurred on 25 April 1974 - the stepping down of Salazar's fascist regime - brought about the initial "democratization" of Lisbon's nightlife. Hence, Cais do Sodré was re-appropriated by the young middle classes, university students, bohemians, intellectuals, and local journalists once democracy was restored. Today these social groups have become key agents in promoting the new cool nightscape that has recently emerged in Cais do Sodré.

However, nothing of the past continues to exist today. As pointed out by the BBC's journalist Kerry Christiani: "Cais do Sodré had upstaged Bairro Alto as Lisbon's most happening nightlife district" (Christiani 2012). Over recent years, some urban changes have taken place in Cais do Sodré. Its deprivation developed through the twentieth century in terms of building degradation over time and the rise of critical health risks associated with the consumption of alcohol, drugs, and marginal prostitution; but it found a first solution in the late 1970s through the promotion of a bohemian nightlife among university students, liberal professionals such as journalists, writers, singers and musicians, and young politicians, among others. In fact, they felt free of the consuming city after the stepping down of Salazar's 

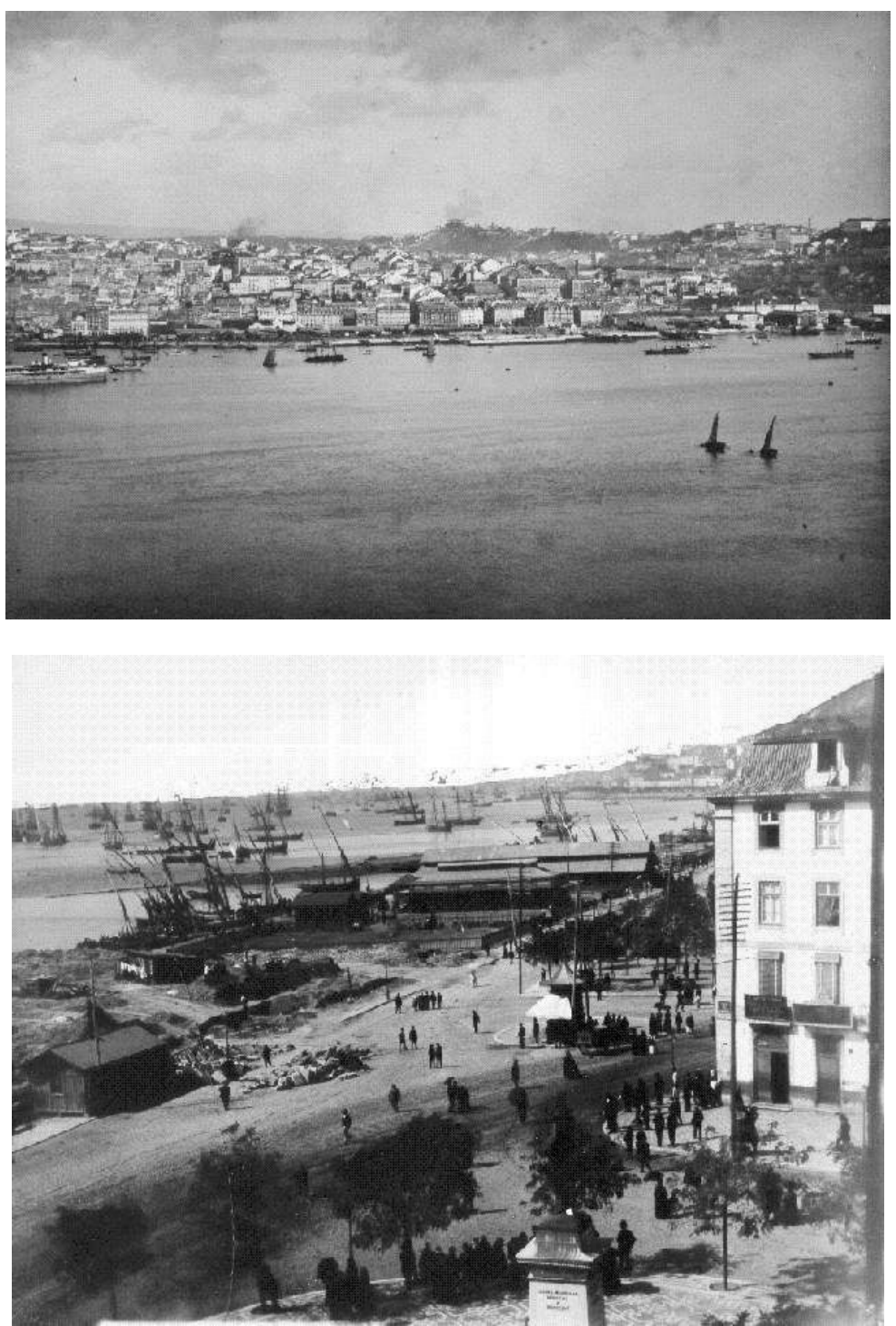

Fig. 2. A sight of the Lisbon waterfront in 1903 (top), and a partial sight of Cais do Sodré in 1900 (bottom). Source: SkyScraperCity $2013 .^{2}$ fascist regime (1933-1974). However, in the 1990s this bohemian nightlife in Cais do Sodré was rapidly replaced by a new one, which was much more oriented to global mass tourism. Till two years ago, tourists, young local people, and Erasmus students had been consuming an urban nightscape in which drugs, marginal prostitution, police, and some few high purchasing power customers had coexisted.

In 2010 the City Council approved support for new private initiatives to transform Cais do Sodré into a new hub of cultural production and con- sumption especially oriented to the new middle classes (Florida 2000) and local upper-middle classes, as Section 6 accurately depicts. It meant to support gentrification in the former harbour quarter of Cais do Sodré. However, what has been commented on to date about gentrification, rent-gap, and value-gap theories may not be helpful for highlighting how this area of the Portuguese capital is currently being gentrified through a new socially sanitized nightlife based on the newly-emerged vintagestyle decoration of nightlife venues. 


\section{Consuming "the vintage" as a new form of social distinction}

In several South-European cities like Lisbon, the consumption of vintage fashion seems to have reemerged as sign of class-based distinction. In the case of the Portuguese capital, this process is closely linked to the recent rise of the local pin-up movement as a new form of youthful hedonism. For example, two recently-opened stores of pin-up and vintage furniture, art, goods, clothes, and memorabilia located in the gentrified neighbourhood of Bairro Alto (Mendes 2006) - namely Bad Luck (closed in Autumn 2010) and Ás de Espadas - have been satisfying this demand for youthful hedonistic consumption (Veenhoven 2003; Goss 2004; Baptista 2005; Migone 2007). In fact, Le Cool Magazine Lisboa labelled Ás de Espadas (Fig. 3) as one of the best fashion boutiques in Lisbon (Rosa 2010).

On the other hand, the recent re-inauguration of the 1940s-styled Hotel Flórida in one of the wealthiest area of Lisbon (Duque de Palmela Street) is not a mere coincidence. Many night-time parties and performances have recently favoured the re-emergence of both the pin-up and vintage movements as an alternative to mainstream nightlife promotion in the Portuguese capital. In this alternative (and distinctive) movement, the Cais do Sodré Cabaret Association plays a key role:

"CAIS SODRÉ CABARET! aims to celebrate the times when gentlemen wore hats and ladies wore gloves...a celebration of style and glamour of another epoch. In Portugal, during the 20s and 30s, there were many clubs and cafes that held writers, artists and intellectuals' meetings... . We aim to recreate a retro-atmosphere associated with bohemian night life celebration where party and pleasure are priority: music, dancing, drinking and smoking, but also sordid and decadent atmosphere of Cais do Sodré. It was on its dark and dirty alleys, street corners and sidewalks, illuminated by neon light announcing bars with revered city names, where hooker ladies and their pimps, policemen, dockers and all kinds of clients hungry for emotions walked on by, where sailors brought in the first American rock ' $n$ ' roll records. All these spirits are invoked in the party!" (Cais do Sodré Cabaret, General Information - Facebook Account, 2012).

At the beginning of the twentieth century, the Cais do Sodré neighbourhood was characterized by a sordid atmosphere. Today, such sordidness has been re-signified into a vintage atmosphere associ-
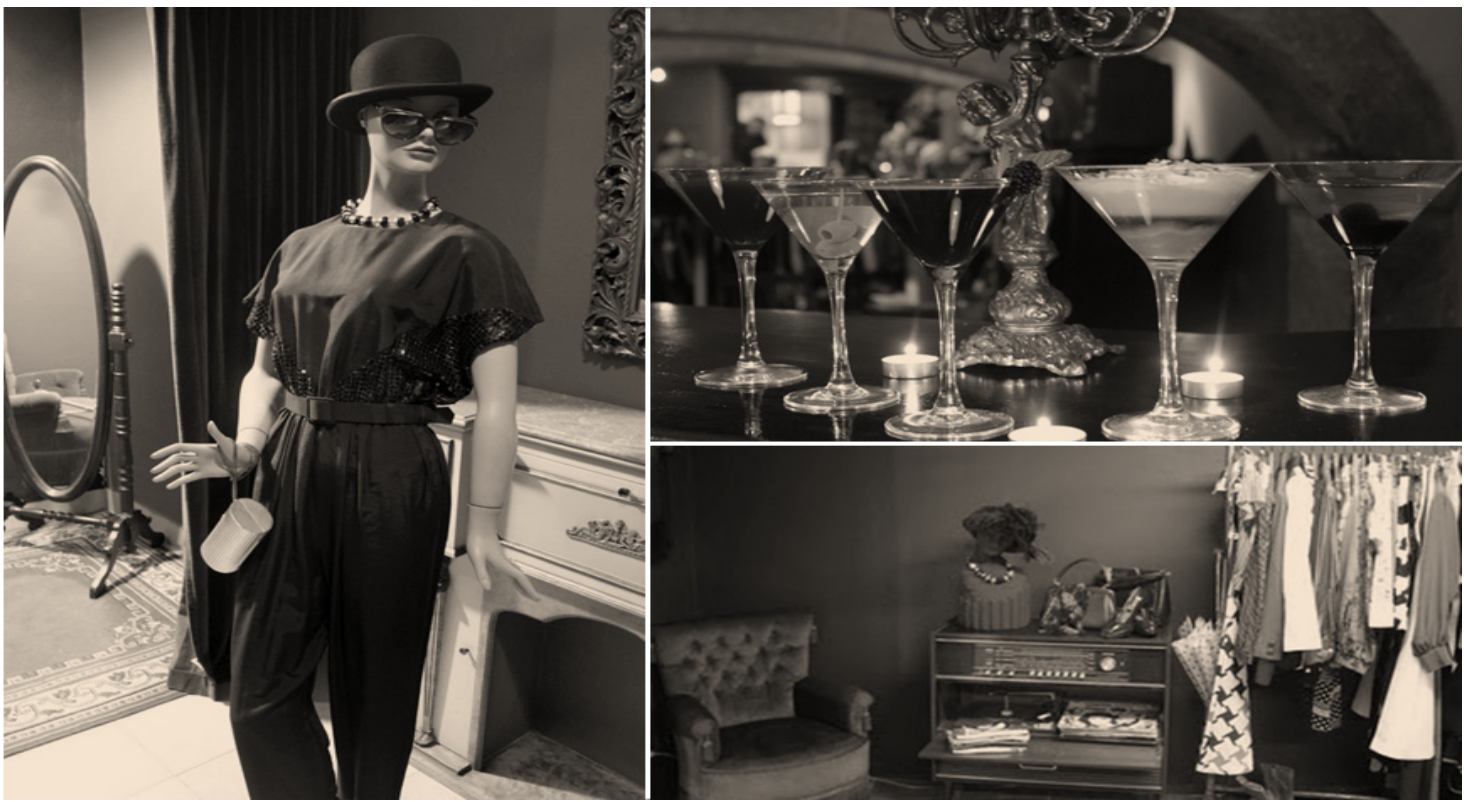

Fig. 3. Vintage design and consumption of distinction in the "Ás de Espadas" store, Lisbon. Source: Loja Ás de Espadas @ 2012. 
ated with a socially sanitized bohemian nightlife which is mainly oriented towards the local new middle classes. The next section shows how such a re-signified, distinguished vintage-like atmosphere has elitized a formerly decadent working-class urban nightscape. In doing this, this paper aims to observe how vintage style is socially recognizable and highly valued because of its commitment to a specific distinguished authenticity, which is largely inherited from the one that originated in the early twentieth-century European bohemia. What we could call a bohemianized distinction therefore seeks to be radically differentiated from the mass (and vulgar) leisure consumption. It thus becomes a mechanism for social distinction and the accumulation of cultural capital (Bourdieu 1979). In short, José Luís Borges' argument about the task of humanity in turning memory into beauty has become a simulated reality, where the memory of decadence and sordidness seems to have been turned into a vintage-styled good for distinctive consumption.

\section{Cais do Sodré: Gentrifying a decadent nightscape in downtown Lisbon}

The democratization of Lisbon's nightlife after the Salazar's fascist regime has also involved a spatial displacement of marginal prostitution. Today, this process has been reinforced, as reported by journalist Clara Silva (2011):

"In Pensão Amor, there are still beds, cabinets, chairs and mirrors of the times when the building housed prostitution. In fact, they then run four hostels which rented rooms per hour to prostitutes and sailors arrived from various parts of the world who had docked for some days at Cais do Sodré. Nowadays rooms can also be rented daily, weekly or monthly, but just to companies - which have nothing to do with prostitution."

In fact, the small bridge of Rua do Alecrim divides the nightlife area of Cais do Sodré into two parts (Fig. 4). In its western area three newlyopened, vintage-styled venues (Pensão Amor, Bar da Velha Senhora, and Sol e Pesca) offer a nightlife almost exclusively for the local and global new upper-middle classes. However, some of the young lower-middle classes (mostly local university students) also frequent these venues to avoid the sordidness that exists in the eastern side (Informant 1), where small-sized traditional discotheques that opened in the beginning of the 1970s (Jamaica, Viking, Europa Bar, Oslo Bar, Liverpool Bar, Copenhagen Bar, and Tokyo) continue to offer Cais do Sodré's traditional nightlife: cheap beer, cut-rate liquors, aged prostitutes, drugs traffic (hashish and cocaine), the same classic hits from the 1970s sounding every night, the original indoor design, and so on.

However, this decadent atmosphere is re-signified by some (white) upper-middle class adults, many of whom work in the fields of cinema, journalism, and TV serials (Informant 2). For some of them, it just means remembering those nights spent there when they were younger; for others, it signifies a degraded nightlife full of drug dealers, aged prostitution, Erasmus and local students, sordidness, and so on; all of which have been existing, but these adult riders of the night never interacted with them. They experience a nightlife flooded with controlled emotions in a safe atmosphere guaranteed by the venue's security staff as well as by a significant number of secret police agents (Informant 8).

Needlessly, nightlife has been a great battlefield in socially sanitizing - even gentrifying - the neighbourhoods of several cities worldwide, as has been previously argued. However, the case of the Cais do Sodre neighbourhood in downtown Lisbon is of great interest in better understanding the hidden strategies carried out by local institutions. One example of this would be the pedestrianization of Rua Nova de Carvalho. In a wide sense, such an intervention in a public space should not result in a great public discussion. However, in the late autumn of 2011 the City Council decided to pedestrianize Rua Nova de Carvalho, thus satisfying the demands of venue owners in contrast to the protests of lifelong neighbours who are organized in the association Nós Lisboetas (Sobral 2012). In fact, the neighbours argued that the pedestrianization of Rua Nova de Carvalho responded to the strategy of the City Council of keeping and promoting nightlife as a relevant income source for the city. Moreover, some informants interviewed in this research agreed by pointing out that the City Council decided to paint in pink Rua Nova de Carvalho Street, the main street in the nightlife cluster of Cais do Sodré, to promote some kind of distinguished nightlife. When further asked about some convenient arrangement between the City Council and the elitist Pensão Amor Hostel, most informants considered that it seems there is an institutionally supported strategy of creating a new distinguished nightscape in the Cais do Sodré neighbourhood. It would not be risky to take such statements seriously, as the City Coun- 


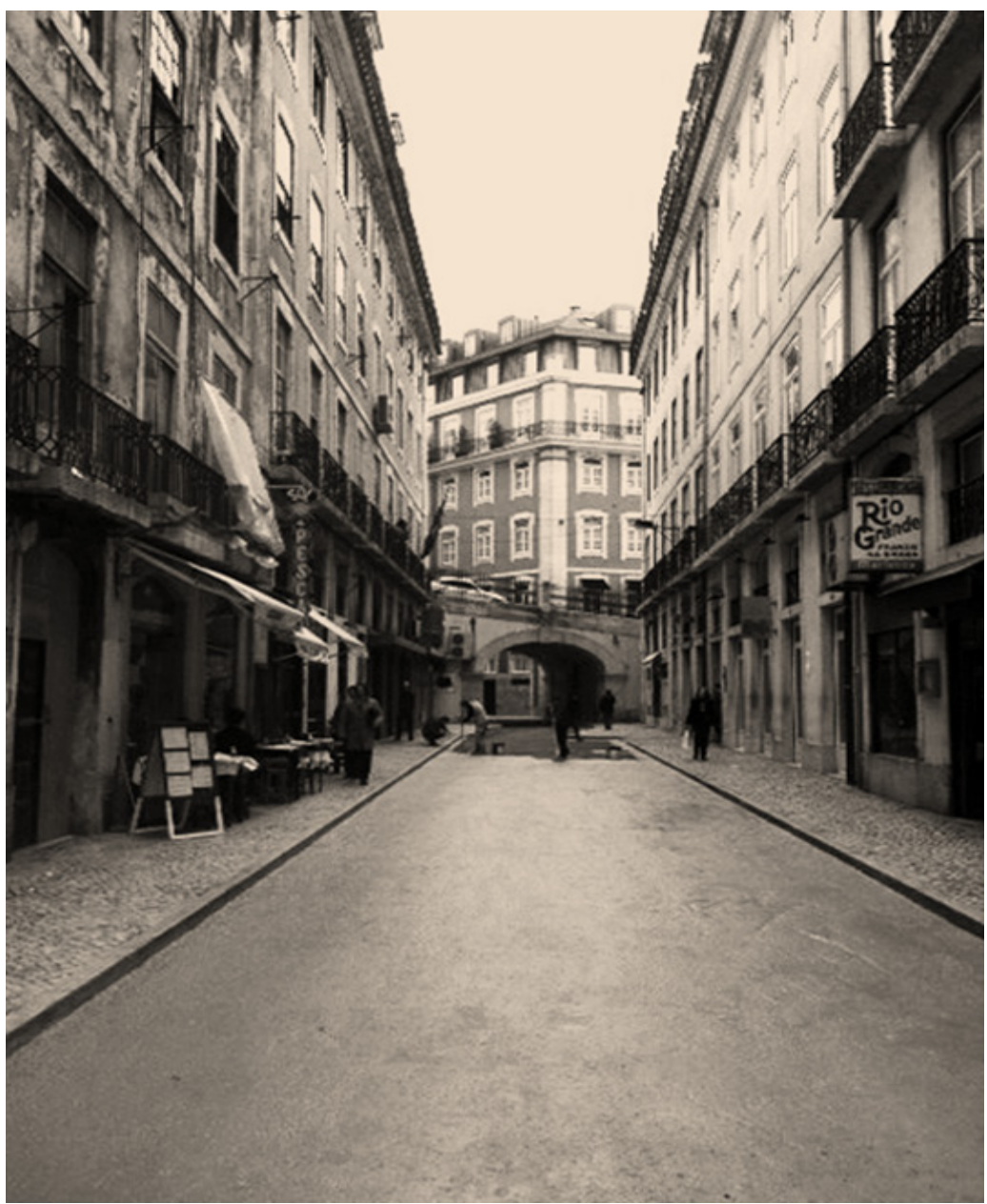

Fig. 4. Cais do Sodré, today. Source:<http://blog.benetton. com/portugal/2012/02/01/caisdo-sodre-pink-connection/> (Image 1, modified by the author). cil recently approved (on 24 April 2013) the urban regeneration plan of Cais do Sodré's waterfront side. In fact, the term "gentrification" did not appear when nightlife consumers were informally interviewed in loco. But, although such a term seems to be consciously avoided by much of the local media from Lisbon, some publications have echoed such a regeneration of the nightscape of Cais do Sodré, as reported by Clara Silva (2011):

"The bar that once attracted American sailors has given rise to the Music Box, one of the trendiest nightclubs in the capital which opened three years ago. DJ battles, concerts and electronic music often attract a young, fashionable clientele and displaced prostitutes... . Texas Bar just left a neon cactus, abandoned in the dark wall of the rear of the Music Box."
However, the reconversion of Cais do Sodré cannot be completely understood without having in mind the role that the newly-opened Pensão Amor Hostel plays in socially elitizing the urban nightscape of this neighbourhood of downtown Lisbon. Pensão Amor occupies an old five-story building: the walls are painted in red, and there are chandeliers and lamps with trinkets, old pictures of seminaked slightly shy ladies in erotic poses, and wooden nineteenth century styled chairs all lending a vintage-style atmosphere to the whole building. Its first floor is a multifunctional space where exhibitions, lectures, and book launches often take place, and it also has a small space to stand up while drinking a cocktail and listening to the DJ session. 

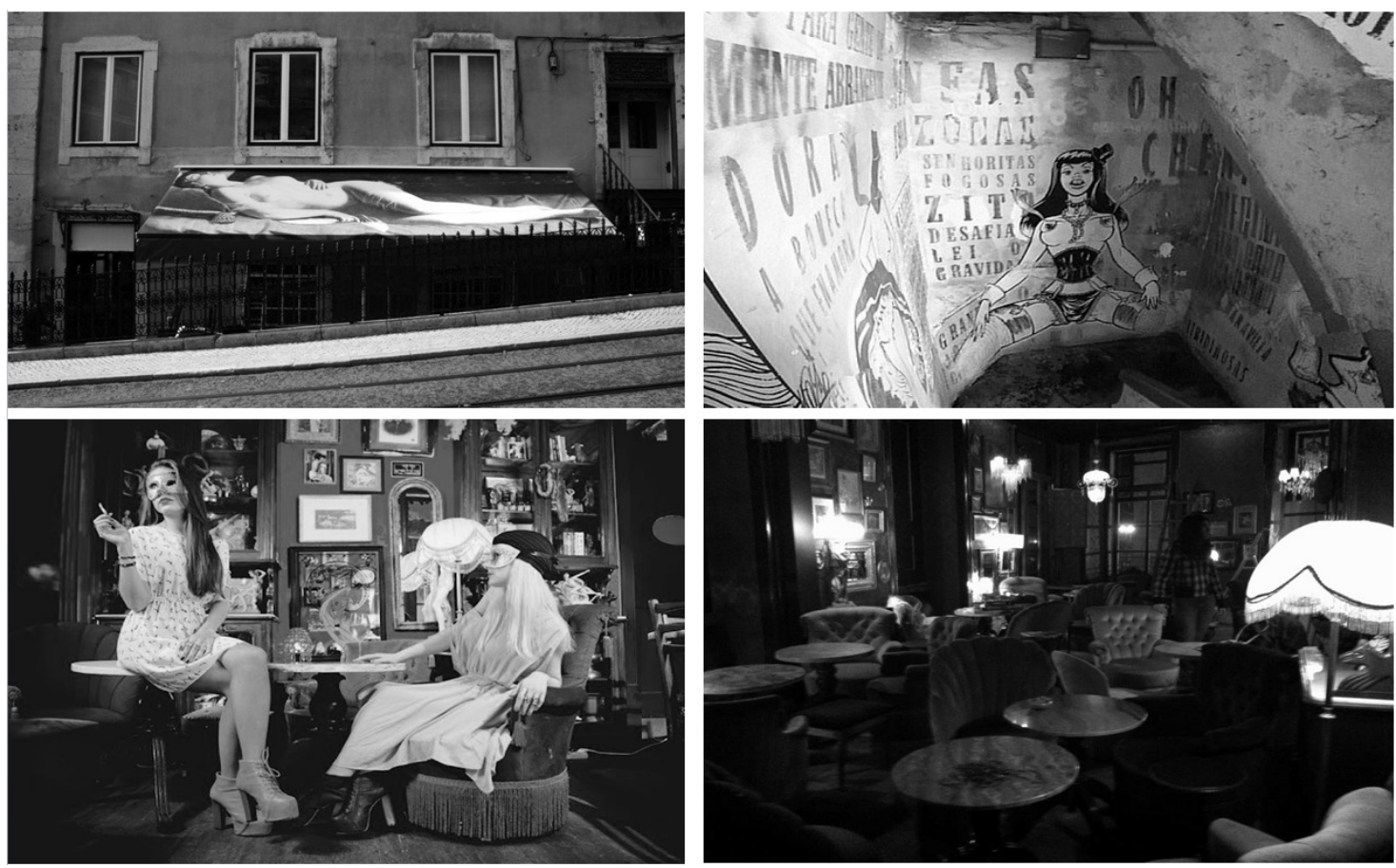

Fig. 5. Inside Pensão Amor: a detail of the first floor (top), and a performance by the Pensão Amor's clientele who are quietly talking (3). Source Images (1, 3 \& 4): Pensão Amor @ 2012. Source Image (2) (top right): Jordi Nofre (c) 2012.

On the rest of the floors, rooms have been renovated to host creative artistic initiatives, including the management office of the Queer Lisbon Festival (Jerónimo 2011). Besides, there is a cabaretstyled room decorated with antique chairs, where clientele can read, talk, and drink distinguishably (see Fig. 5) in a socially sanitized space. (White) bouncers carry out the sanitation of the venue by applying discriminatory criteria based on ethnicity, class, and body appearance. In other words, blacks who migrated from the former Portuguese colonies, gypsies, and anyone who does not appear to belong to the native born middle-upper classes is prohibited from entering the Pensão Amor Hostel. ${ }^{3}$ The social sanitization carried out by the Pensão Amor's bouncers has strong implications for policing Cais do Sodré's nightlife as well as for how security in public spaces is being privatized; in other words, the way privatization and sanitation in public spaces are today gaining importance is an implication of that ecology of fear featured in the nightlife of most of the Western cities (Chatterton \& Hollands 2003).
The BBC-Travel Channel recently reported Pensão Amor as "once a brothel, [it] had been reborn as an art space with a bordello-chic bar" (Christiani 2012). The fact of labelling Pensão Amor as a bordello-chic bar reinforces the hypothesis that this venue is the most important agent in gentrifying nightlife in Cais do Sodré. Furthermore, the use of the term "bordello-chic" suggests some changes in the meaning of the term "bohemia." Such changes refer to two dimensions of the term itself; that is, its spatial and behavioural dimension. First, Pensão Amor offers an indoor design space reminiscent of the bohemian nightclubs of the most culturally active world cities during the decades of the 1920s and 1930s such as, for example, Chicago, Paris, and New York. However, most of the changes in the meaning of the term "bohemia" refer to its behavioural dimension, and involve a new sanitized vision about what bohemia means. As argued by the Portuguese journalist Sancha Trindade, "... with warm colours, hanging mirrors, an old piano and flooded with sexy photos of several decades ago, the seductive atmosphere al- 

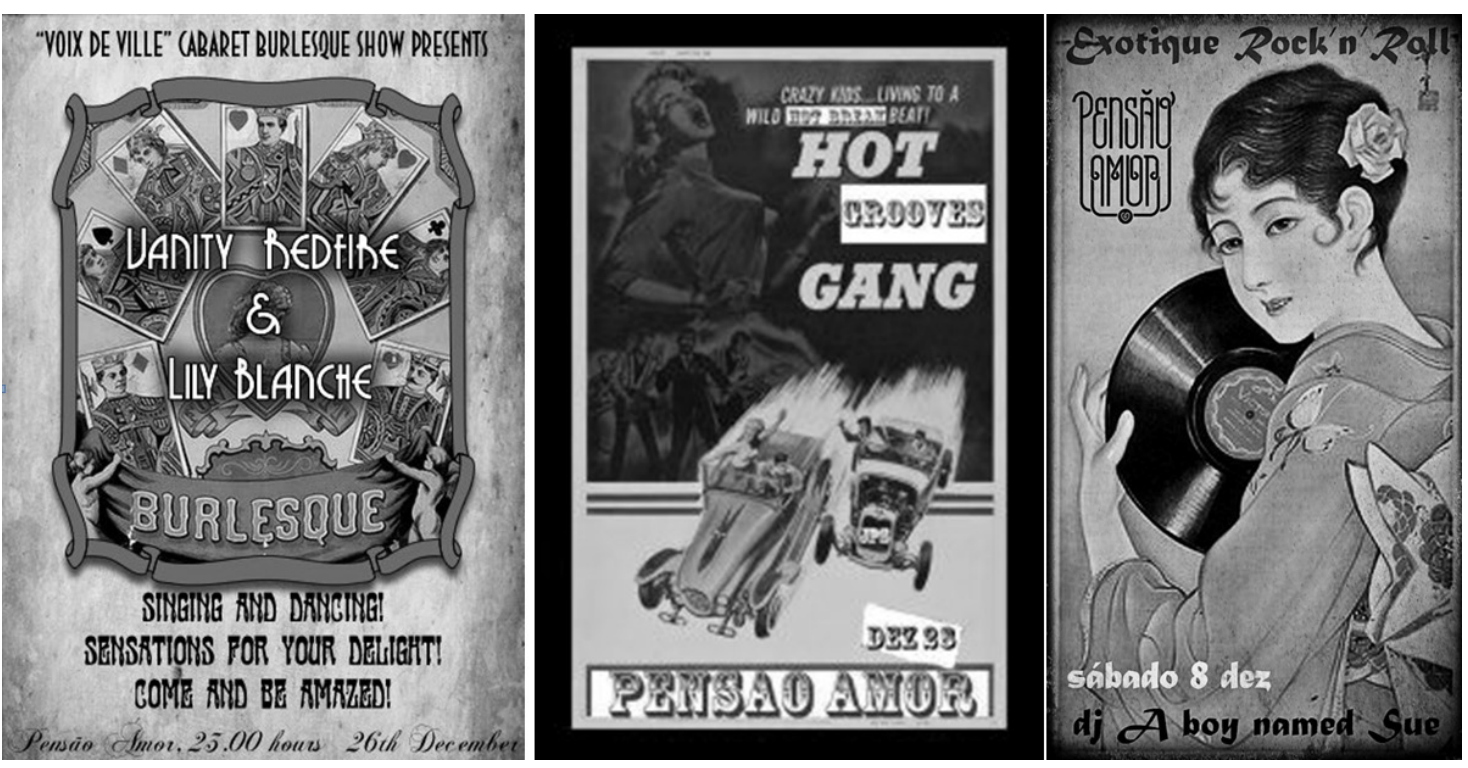

Fig. 6. Some vintage-style flyers of Pensão Amor. Source: Pensão Amor (C) 2012.

ready confirms the future success of Pensão" (Trindade 2011). In that sense, Pensão Amor offers a socially sanitized menu of night-time elegance, predictable pleasure, and controlled fantasy for its clientele (Fig. 6).

However, if bohemianism, luxury consumption, new sexual and drugs experimentation, as well as youth culture and social informality have appeared as the most recognized social values during the interwar period in the twentieth century, then today's meaning of bohemia has been socially sanitized. Explicit desires for sexual experimentation shown through dress codes have become a taboo, while dress experimentation is also prohibited. On the other hand, the fact of explicitly belonging to any working-class youth subculture ${ }^{4}$ makes it very difficult to access Pensão Amor, which contrasts with the members of any (white) middle-class subculture, such as hipsters (Informants $3 \& 4$ ). Moreover, individual behaviours such as exultation, explicit happiness, laughing loudly, drink quickly, or sensual dancing are seen as inappropriate: "Many African and Brazilian dances often imply body exposure, and physical contact. It is awful" (Informants $5,6,7)$.

On the other hand, social informality that once featured at bohemian venues, where writers, jour- nalists, and artists usually gathered, has given way to predictable, scripted de-politicized conversations. In the transformation of the bohemian into the vintage, glasses of wine, cocktails, and cigarettes still continue to decorate tables even after several decades, while political conversation has been eradicated. The vintage nightlife has been de-politicized, socially sanitized, and morally controlled. As argued by Mikas, "Many people join prostitutes and bars when they think of Cais do Sodré. We aim to take this popular knowledge that goes from the burlesque to the carbaret and to safely retain the aesthetic nature of the indoor space without it being irreverent" (Mikas 2011, cited in Silva 2011).

\section{Final remarks}

Mikas, together with Nuno, Ricardo, and João Nuno are the owners of Bar da Velha Senhora (Silva 2011), the other vintage-style nightclub located just on the ground floor of the Pensão Amor's building. At the opening of Pensão Amor, they had counted on the financial and logistical support of Mainside, a real estate company which also participated in the opening of the LX Factory - a cul- 
tural production cluster recently opened in Alcântara, one of the harbour neighbourhoods of the Lisbon waterfront side such as Cais do Sodré - as well as in the inauguration of the LX Boutique Hotel in Rua de Alecrim, in front of Pensao Amor itself.

The fact that real-estate company Mainside owns Pensão Amor, Bar da Velha Senhora, LX Boutique Hotel, and LX Factory may reinforce the idea of the beginning of the process of gentrification in the Cais do Sodré neighbourhood, which is mainly characterized at the moment by elite night-time leisure activities. The Pensão Amor Hostel and its popularity among the local upper-middle classes demonstrates the resilience and flexibility of local small-scale nightlife, and its importance in gentrifying and socially sanitizing downtown Lisbon. In that sense, this paper has presented the first results of a 2-year ethnographic fieldwork study of urban changes and nightlife promotion in Lisbon by describing the case of a newly emerged vintage-style nightlife in the former harbour quarter of Cais do Sodré (downtown Lisbon).

This paper has shown how such recentlyemerged nightlife is currently playing a key role in gentrifying the nightscape of this urban area, where the traditional nightlife is today being supplanted by vintage-style nightlife. To exemplify such a transformation, this paper has prioritized a significant place, the Pensão Amor Hostel, which plays a key role in remaking a socially sanitized and morally controlled new nightscape, marginalizing everyone who is seen to be inappropriate, socially perilous, and unfit in the process of the city branding of Lisbon: the authentic bohemia in Cais do Sodré continues to smell of salt and sweat, wine and sex.

Many authors have explored the different forms that gentrification has recently adopted around the world, by labelling it as post-industrial gentrification, new urban colonialism, and so on. The adjective 'post-industrial' does not matter here, but gentrification itself is a process of social sanitization and a violation of the right to the city as well. In studying the nightlife of Cais do Sodré, this paper has not pretended to analyse how its gentrification has occurred, but it has explored how customers consume its vintage-style aesthetics as a new form of social distinction, and how such consumption appears to be a mechanism for sanitizing Cais do Sodré's nightlife. There are many common aspects of the way gentrification operates across the entire world; however, the social and cultural peculiari- ties of places involve gentrification adopting different aesthetics according to local distinctiveness. Maybe we scholars should take into account again what Loretta Lees (2000) suggested regarding gentrification as the cure-all for inner-city ills that can verify the dullest natured politicians and technicians governing our cities. In short, here we would support what Max Haivens (2010) stated: "The financial crisis as a crisis of imagination".

Today's financial and real-estate crisis has provoked a situation where gentrification seems to be much more fragmented than a few years ago (Mendes 2011). Great urban transformations in downtown areas have given way to marginal gentrification that only takes place in some restricted parts of the city (Rose 1984; Mendes 2011). This does not mean that gentrification is on its last legs. As this paper has shown, in the case of the Pensão Amor Hostel, some selected buildings have become agents of this newly-emerged marginal gentrification. We scholars should continue to explore how it is re-bordering urban inequalities in our post-industrial cities, where a sanitized nightlife is going to play a key role for a long time.

\section{NOTES}

${ }^{1}$ For two main reasons, not all of the participants have been quoted in this text. The first reason is obvious, as the editorial board of this journal limits the text length, and not all can be fitted in this paper. The second reason is that the research I present here will be part of a three-paper series on Lisbon's nightlife to be published in the near future.

2 Please, note that these pictures, which are part of the Historical Archive Fund of Lisbon have been downloaded from the forum "SkyScraperCity", one of the most important online forums on urban issues, because of restricted access to the Portuguese National Library of Torre do Pombo in 2010 and 2011 due to remodeling works. Source (top image): <http://www.skyscrapercity.com/showthread.php?t=563620\&page $=7>$. Source (bottom image): <http://www.skyscrapercity.com/showthread. php? $t=563620 \&$ page $=10>$ (both accessed on 4 January 2013).

${ }^{3}$ Nightlife segregation in Lisbon may also be seen as a reflection of urban segregation in the Portuguese capital. Black lower-class immigrants who have arrived from former Portuguese colonies are housed in poor housing conditions in segregated neighbourhoods (Baptista 2011). Hence, everyday segmented social practices include night-time leisure activities.

${ }^{4}$ This paper does not intend to discuss the tension between youth subcultures, youth nightlife, and middle-class lifestyle, although some studies may consider that it is central to many cases where nightlife is promoted in the gentrification of areas. 


\section{ACKNOWLEDGEMENTS}

This work has been supported by the Fundação para a Ciência e a Tecnologia de Portugal (FCTT-SFRH/ BPD/63178/2009) and the Centro de Estudos de Sociologia da Universidade Nova de Lisboa (CesNova). I would like to also thank Professor Marc Oliva (IGOT-UL) by his support in doing fieldwork as well as his ideas, reflections, discussions and "particular" points of view about nightlife.

\section{REFERENCES}

Atkinson R \& Brigde G (eds) 2008. Gentrification in a Global Context: a new urban coionialism. Routledge, New York.

Baptista L 2005. Territórios Lúdicos (e o que se torna lúdico um território): Ensaiando um ponto de partida. Fórum Sociológico 13-14: 47-58.

Baptista L (ed) 2011. A construção da metrópole: segregação urbana e intervenção pública em Lisboa (1950-2011). Final Project Report. Lisboa, CesNova, Faculty of Social Sciences and Humanities, New University of Lisbon.

Berry BJL 1980. Forces reshaping the settlement system. In Bryce H (ed). Cities and Firms. Lexington Books, Lexington.

Bourdieu P 1979. La distinction. Éditions de Minuit, París.

Butler T 1997. Gentrification and the middle classes. Ashgate, Aldershot.

Butler T 2007. For gentrification? Environment and Planning A 39: 1, 162-181. http://dx.doi.org/10.1068/ a38472.

Castells M 2012. Networks of outrage and hope. Social movements in the internet age. Polity Press, New York.

Chatterton P \& Hollands R 2003. Urban nightscapes: youth cultures, pleasure spaces and corporate power. Routledge, New York.

Christiani K 2012. The rebirth of Lisbon's Cais do Sodré. BBC-Travel Channel. <http://www.bbc. com/travel/feature/20120320-the-rebirth-of-lisbons-cais-do-sodre> 8.3.2013.

De La Barre J 2010. Music, city, ethnicity: exploring musical scenes in Lisbon. Migrações - Special Issue Music and Migration 7: 39-156.

Durão VCM 2012. Reclaimed land: an urban analysis - The landfills in Lisbon's downtown and riverfront. Journal of Integrated Coastal Zone Management 12: 1, 17-30.

Eurocities 2001. Culture: The engine of the 21st Century European cities. European Commission, Brussels.

Florida R 2000. The rise of the creative class: and how it's transforming work, leisure, community and everyday life. Basic Books, New York.

França JA 2013. Lisboa - historia física e moral. Livros Horizonte, Lisboa.
Galtung J 1958. The social functions of a prison. Social Problems 6: 2, 127-140.

http://dx.doi.org/10.1525/sp.1958.6.2.03a00050.

Garnier JP 2010. Une violence éminentmment contemporaine. Essais sur la ville, la petite bourgeoisie intellectuelle \& I'effacement des classes populaires. Contre-Feux Agone, París.

Glass R 1964. London: Aspects of Change. Centre for Urban Studies and MacGibbon and Knee, London.

Goss J 2004. Geography and consumption - I. Progress in Human Geography 28: 3, 369-380. http:// dx.doi.org/10.1191/0309132504ph486pr.

Groves ER 1916. Moral Sanitation. New York, Association Press.

Hael L 2011. Dilemmas of the nightlife fix: post-industrialization and the gentrification of nightlife in New York City. Urban Studies 48: 6, 3449-3465. http://dx.doi.org/10.1177/0042098011400772.

Haivens M 2010. The financial crisis as a crisis of imagination. Cultural Logic: An Electronic Journal of Marxist Theory \& Practice 17.

Hamnett C 1973. Improvement grants as an indicator of gentrification in Inner London. Area 5, 252-61.

Hamnett C 2003. Gentrification and the middle-class remaking of inner London 1961-2001. Urban Studies 40: 12, 2401-26. http://dx.doi.org/10.108 0/0042098032000136138.

Hamnett C \& Randolph B 1984. The role of landlord disinvestment in housing market transformation: an analysis of the flat break-up market in central London. Transactions of the Institute of British Geographers 9, 259-79.

Hamnett C \& Randolph B 1986. Tenurial transformation and the flat break-up market in London: the British condo experience. In Smith N \& Williams P (eds.). Gentrification of the city, 121-152. Allen and Unwin, Boston.

Hannerz U 1980. Exploring the City. Towards an Urban Anthropology. Columbia University Press, New York.

Hannigan J 1998. Fantasy city: pleasure and profit in the postmodern metropolis. Routledge, New York.

Jerónimo A 2011. Cais do Sodré é sexy! Pensão Amor, Bar da Velha Senhora e O Povo: A troika de bares que veio arrasar a noite Lisboeta, Ruadebaixo 76. $<$ http://www.ruadebaixo.com/cais-do-sodresexy-como-nunca.htm/http://www.ruadebaixo. com/cais-do-sodre-sexy-como-nunca.html> 26.3.2012.

Lees L 1994. Gentrification in London and New York: an Atlantic gap? Housing Studies 9: 2, 127-32. http://dx.doi.org/10.1080/02673039408720783.

Lees L 2000. A reappraisal of gentrification: Towards a 'geography of gentrification. Progress in Human Geography 24: 3, 389-408.

http://dx.doi.org/10.1191/030913200701540483.

Lees L \& Bondi L 1995. De/gentrification and economic recession: the case of New York city. Urban Geography 16, 234-53.

http://dx.doi.org/10.2747/0272-3638.16.3.234. 
Lefebvre H 1968. Le Droit à la Ville. Anthropos, Paris.

Ley D 1980. Liberal ideology and the postindustrial city. Annals of the Association of American Geographers $70,238-58$.

http://dx.doi.org/10.1111/j.1467-8306.1980.tb01310.x.

Ley D 1986. Alternative explanations for inner-city gentrification. Annals of the Association of American Geographers 76, 512-35.

http://dx.doi.org/10.1111/j.1467-8306.1986.tb00134.x.

Ley D 1997. The new middle class and the remaking of the central city. University Press, Oxford.

Ley D 2003. Artists, aestheticisation and the field of gentrification. Urban Studies 40: 12, 2527-2544. http://dx.doi.org/10.1080/0042098032000136192.

Maeckelbergh M 2012. Mobilizing to stay put: housing struggles in New York City. International Journal of Urban and Regional Research 36: 4, 653-673.http:// dx.doi.org/10.1111/j.1468-2427.2012.01120.x.

Manchester Literary \& Philosophical Society 1888. Memoirs and Proceedings of the Manchester Literary \& Philosophical Society.

Mendes L 2006. A nobilitação urbana do Bairro Alto: Análise de um processo de recomposição sócioespacial. Finisterra 41, 57-82.

Mendes L 2011. Cidade pós-moderna, gentrificação e produção social do espaço fragmentado. Cadernos Metrópole 26, 473-495.

Migone A 2007. Hedonistic consumerism: patterns of consumption in contemporary capitalism. Review of Radical Politics Economics 39: 2, 173-200. http://dx.doi.org/10.1177/0486613407302482.

Miraftab F 2007. Decentralization and entrepenurial planning. In Beard VA, Miraftab F \& Silver C (eds.). Planning and decentralization: contested spaces for public actions in the global south, 21-35, Routledge, New York.

Musterd S \& Van Weesep J 1991. European gentrification or gentrification in Europe. In Van Weesep J \& Musterd S (eds.). Urban housing for the better-off: gentrification in Europe, 11-16. Stedelijke Netweken, Utrecht.

Nofre J 2011. Youth policies, social sanitation, and contested suburban nightscapes. In Perrone C, Manella G \& Tripodi L (eds). Research in Urban Sociology 11. Emerald Group Publishing. http:// dx.doi.org/10.1108/S1047-0042(2011)0000011015.

Nofre J \& Feixa C 2013. Policies of inclusion? Some thoughts on the 'Los Indignados' movement, the emerging of the neoliberal penal state and the criminalization of 'being young' in Southern Europe. In Rethinking Urban Inclusion, _Cescontexto_/Debates 2. University of Coimbra Press, Coimbra (Portugal). <http://www.ces.uc.pt/publicacoes/cescontexto/ficheiros/cescontexto_debates_ii.pdf> 5.5.2012.

Nofre J \& Martin J 2009. Ocio nocturno, gentrificación y distinción social en el centro histórico de Sarajevo [Nightlife, gentrification, and social distinction in downtown Sarajevo]. Anales de Geografía de la Universidad Complutense de Madrid 29: 1, 91-110.
Ritzer G 1993. The McDonaldization of society. Pine Forge Press, Thousand Oaks, CA.

Ritzer G 1998. The McDonaldization thesis: explorations and extensions. Sage, London.

Ritzer G 2010. Enchanting a disenchanted world: continuity and change in the cathedrals of consumption. Sage, New York.

Rosa L 2010. Loja Vintage: Ás de Espadas. Le Cool Magazine Lisboa, October 2010. <http://spoiledmilk.lecool.com/lisboa/pt/2627?show_share_ panel=true $>12.4 .2012$.

Rose D 1984. Rethinking gentrification: beyond the uneven development of Marxist urban theory. Environment and Planning D: Society and Space 2: 1, 47-74. http://dx.doi.org/10.1068/d020047.

Savage M \& Butler T 1995. Social change and the middle classes. Routledge, London.

Silva C 2011. Cais do Sodré. Os novos inquilinos chegam à Pensão Amor e ao Bar da Velha Senhora [Cais do Sodré. New dwellers arriving at Pensão Amor and Bar da Velha Senhora]. ionline, 10 November 2011.

Smith N 1979a. Toward a theory of gentrification: a back to the city movement by capital not people. Journal of the American Planning Association 45, 538-548. http.//dx.doi.org/10.1080/01944367908977002.

Smith N 1979b. Gentrification and capital: practice and ideology in Society Hill. Antipode, A Radical Journal of Geography 3: 2, 24-35. http://dx.doi. org/10.1111/j.1467-8330.1985.tb00346.x.

Smith N 1996. The new urban frontier: gentrification and the revanchist city. Routledge, New York.

Smith N 2002. New globalism, new urbanism: gentrification as global urban strategy. Antipode 34: 3, 427-450.http://dx.doi.org/10.1111/14678330.00249.

Sobral C 2012. O Cais do Sodré mudou e os moradores não estão a gostar. Público, 7 April 2012.

Stearms AW 1936. The evolution of punishment. Journal of Criminal Laws and Criminology 27: 2, 219-230.

Thornton S 1995. Club cultures: music, media and subcultural capital. Polity Press, Cambridge.

Thrasher FM 1926. The gang: a study of 1313 gangs in Chicago. University of Chicago Press, Chicago.

Trindade S 2011. Hoje, beijo-te Lisboa [Today, I kiss you, Lisbon]. Vogue Magazine, 17 November 2011.

Vangby B \& Jensen OB 2009. From slum clearance to urban policy: discourses and doctrines in Dannish inner city redevelopment. Housing, Theory \& Society 19: 1, 3-13.

http://dx.doi.org/10.1080/140360902317417895.

Veenhoven R 2003. Hedonism and Happiness. Journal of Happiness Studies 4, 437-457. http://dx.doi. org/10.1023/B:JOHS.0000005719.56211.fd.

Wacquant L 2008. The militarization of urban marginality: lessons from the Brazilian Metropolis. International Political Sociology 2, 56-74. http:// dx.doi.org/10.1111/j.1749-5687.2008.00037.x. 
Walker C \& Fincham B 2011. Techniques of Identity Governance and Resistance: Formulating the Neoliberal Worker in Work and the Mental Health Crisis in Britain. John Wiley \& Sons, Cichester.

Weatherly UG 1926. Haiti: an experiment in pragmatism. American Journal of Sociology 32: 3, 353-366.

Welch M 2009. Punishment in America: social control and the ironies of imprisonment. Sage, Thousand Oaks, CA.

Whyte WF 1943. The street corner society. University of Chicago Press, Chicago.

Williams P 1976. The role of institutions in the inner London housing market: the case of Islington. Transactions of the Institute of British Geographers 1, 72-82.
Wilson D \& Grammenos D 2005. Gentrification, discourse, and the body: Chicago's Humboldt Park. Environment and Planning D: Society and Space 23:2, 295-312. http://dx.doi.org/10.1068/ d0203.

Wynne D \& O'Connor J 1998. Consumption and the postmodern city. Urban Studies 35: 5-6, 84164. http://dx.doi.org/10.1080/0042098984583.

Zukin S 1982. Loft living: culture and capital in urban change. Rutgers University Press, New Jersey.

Zukin S 2009. Naked city: the death and life of authentic urban places. Oxford, New York. 